\title{
Kotimaiset tiedejulkaisut avoimiksi
}

Anna-Sofia Ruth, Antti-Jussi Nygård, Johanna Lilja ja Lena Lönngren

Journal.fi-portaali on Tieteellisten seurain valtuuskunnan tarjoama palvelu, jota kotimaiset tieteelliset seurat voivat käyttää lehtiensä toimittamiseen ja julkaisemiseen. Palvelu sisältää tällä hetkellä noin 50 eri tieteenalojen lehteä, joista suurin osa on avoimia eli ilmaiseksi ladattavissa ja luettavissa. Palvelu avattiin tammikuussa 2017.

\section{Julkaisujen varastoinnista kohti avointa infrastruktuuria}

Suomessa tieteellisillä seuroilla on merkittävä rooli tieteellisten lehtien ja kirjojen tuottajana. Seurojen joukossa on suuria kustantajia, kuten Suomalaisen Kirjallisuuden Seura ja Svenska litteratursällskapet i Finland, mutta suurin osa kotimaisista tiedelehdistä ja -kirjoista syntyy alakohtaisissa seuroissa, jotka julkaisevat yhtä tai kahta lehteä tai kirjasarjaa. Vain harvalla seuralla on kokopäiväisiä tai edes osa-aikaisia toimittajia tai kustannustoimittajia. Kuten muutakin seuratoimintaa, myös julkaisutoimintaa pyöritetään suurelta osin vapaaehtoistyön varassa. Tieteelliset seurat saavat julkaisutoimintaansa valtionapua, jos julkaisutoiminta ei tuota voittoa.

Tieteellisten seurain valtuuskunta (TSV) on tarjonnut julkaisutoimintaa harjoittaville seuroille palveluita jo vuodesta 1899 eli heti perustamisestaan alkaen. Aluksi palvelut liittyivät julkaisujen varastointiin ja kansainväliseen vaihtoon. Vuonna 1987 perustettiin Tiedekirja hoitamaan seurojen julkaisujen myyntiä, ja samoihin aikoihin seuroille alettiin tarjota myös tukea julkaisujen taitossa ja painotöiden kilpailutuksessa. TSV:n tavoitteena on tukea seuroja julkaisujen levittämisessä, jotta seurojen omat niukat voimavarat voitaisiin käyttää sisällön tuottamiseen.

Sähköisen julkaisemisen palvelut astuivat painetun julkaisutoiminnan tuen rinnalle 1990-luvulla, jolloin TSV oli mukana kehittämässä Elektra-tietokantaa. Elektra on edelleen tärkeä jakelukanava noin kolmellekymmenelle tieteellisen seu-

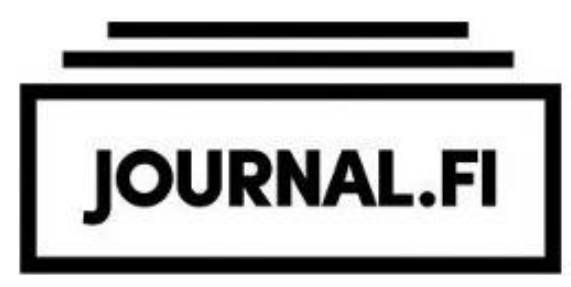

Kuva 1. Palvelun ulkoasun suunnitteli graafikko Marko Myllyaho.

ran julkaisemalle lehdelle. Elektrassa lehtien lukuoikeus perustuu kirjastojen maksamaan lisenssimaksuun, joka mahdollistaa lehdille artikkeleiden latausmääriin perustuvaa tuottoa. Tieteen avoimuuden vaatimusten yleistyessä Elektran käytäntöjä on jouduttu miettimään uusiksi. Syksystä 2016 alkaen Elektra-lehtien on kuitenkin ollut mahdollista sallia vertaisarvioitujen käsikirjoitusten rinnakkaistallennus.

Avoimen julkaisemisen palvelut tulivat ajankohtaisiksi 2000-luvulla. Public Knowledge Projectin (PKP) piirissä kehitettiin avoimia tiedelehtiä varten Open Journal Systems eli OJS-työkalu ja julkaisualusta, jonka tarkoitus oli keventää vertaisarviointi- ja toimitusprosessia, ja siten vähentää avointen lehtien kuluja. OJS on avoimen lähdekoodin ohjelma, jonka kuka tahansa voi ottaa käyttöön ja muokata omiin tarpeisiinsa sopivaksi. TSV ryhtyi kehittämään suomalaista OJS-alustaa yhteispohjoismaisen Nordbib-hankkeen Aiding Scientific Journals Towards Open Access Publishing osana. TSV:n OJS-alusta tuli seurojen käyttöön 2008. Vuoteen 2014 mennessä parisenkymmen- 
tä lehteä käytti sitä julkaisualustana ja lisäksi 17 pelkästään toimitusprosessin apuna.

OJS-käyttäjät eivät kuitenkaan olleet järjestelmään varauksettoman tyytyväisiä. Varsinkin sen tarjoamaa ulkoasua pidettiin kelmeänä. TSV:n ongelmana oli, ettei järjestelmän ylläpitoa ja kehittämistä pystytty resursoimaan riittävästi. Versionvaihdosten jäljiltä toimitustyökaluun ilmaantui virheitä, jotka aiheuttivat julkaisijoille hankalia tilanteita. Näistä syistä TSV:n tarjoaman OJSalustan vetovoima ei riittänyt tavoittamaan kaikkia avoimia tiedelehtiä, vaan osa piti parempana Wordpress-pohjaista julkaisua tai omille verkkosivuille linkitettyjä PDF-artikkeleita.

Lisäksi 2010-luvun tiedepoliittiset muutokset loivat tarpeita, joihin TSV:n OJS-järjestelmä ei enää pystynyt vastaamaan. Näitä olivat mm. identifioinnin mahdollistavien tunnisteiden liittäminen artikkeleihin sekä artikkelien metadatan automaattinen siirto ARTO-viitetietokantaan ja avoimia vertaisarvioituja tiedelehtiä listaavaan Directory of Open Access Journals (DOAJ) -palveluun.

Kotimaisten tiedelehtien asema oli vahvasti esillä, kun opetus- ja kulttuuriministeriössä suunniteltiin Avoin Tiede ja Tutkimus (ATT) -hanketta. Tässä yhteydessä tarjottiin TSV:lle ja Kansalliskirjastolle mahdollisuutta hakea rahoitusta hankkeelle, jolla etsittäisiin ratkaisua paitsi julkaisuinfrastruktuurin uudistamiseen myös siihen, miten avoimet tiedelehdet rahoittaisivat toimintansa tilaus- ja lisenssimaksuista saatavan tuoton jäädessä pois. Hankesuunnitelma Kotimaiset lehdetavoimiksi ja vaikuttamaan (Kotilava) sai rahoituksen keväällä 2015.

TSV:n osuus, joka käsitti OJS-järjestelmän uudistamisen, pääsi käyntiin syksyllä2015. Rahoitusmallin suunnittelu käynnistyi Kansalliskirjastossa maaliskuussa 2016. Näillä osahankkeilla on yhteinen ohjausryhmä, ja niiden edistämisessä on hyödynnetty kummankin osapuolen asiantuntemusta.

\section{Journal.fi:n ensiaskeleet}

Uuden OJS-alustan kehittämistä hidasti se, että päädyttiin odottamaan uuden version OJS 3.0:n julkaisemista, joka lopulta venyi elokuun 2016 loppuun. Suunnitteluaikaa oli siis runsaasti, kun taas lopullinen toteutus ja lehtien toimituskunnan kouluttaminen uuden järjestelmän käyttöön jouduttiin toteuttamaan muutamassa kuukaudessa. Palvelun ulkoasu suunniteltiin syksyn aikana, samoin laadittiin Suomen tiedekustantajien liiton rahoittamana järjestelmän uusi suomennos. Palvelun nimeksi valittiin Journal.fi, sillä palvelussa on mukana kotikielisten julkaisujen lisäksi myös englanninkielisiä ja monikielisiä lehtiä.

Journal.fi-lehtiportaali avattiin yleisölle 24.1.2017. Palvelua rakentamassa oli kolmisenkymmentä lehteä, joiden aineisto siirrettiin uuteen järjestelmään. Palvelun etusivua kehitettiin niin, että pelkän lehtilistauksen lisäksi sieltä löytyvät nyt palvelussa julkaistut uusimmat numerot sekä luetuimmat artikkelit.

Työ ei päättynyt portaalin avaamiseen, vaan kevään aikana lehdille järjestettiin koulutusta DOI-tunnusten käyttöönotosta, rahoittajatietojen linkittämisestä metadataan ja XML-artikkelien tuottamisesta. Kaksi viimeksi mainittua osiota saivat rahoitusta EU:n 7. puiteohjelman hankkeesta Post Grant Open Access Pilot Alternative Funding Mechanism. Lisäksi palvelun käytöstä on laadittu sopimukset lehtiä julkaisevien TSV:n jäsenseurojen kanssa.

Palvelun käyttö on nyt mahdollista myös TSV:n ulkopuolisille julkaisijoille. Tällöin julkaisun on kuitenkin oltava välittömästi ja kokonaan avoin. Lisäksi julkaisun tulee tuoda esiin tieteellisen tutkimuksen tuloksia ja julkaisijan on oltava suomalainen. Ulkopuolisilta käyttäjiltä peritään vuosimaksu, koulutuksesta ja laajemmasta tuesta veloitetaan erikseen. Palvelun kuvaus ja ajantasainen hinnoittelu löytyvät https://www.tsv.fi/fi/palvelut/avoimen-julkaisemisen-palvelut -sivulta.

Journal.fi-portaalissa julkaistaville TSV:n jäsenseurojen lehdille hyväksytään enintään 12 kuukauden viive eli embargo. Tavoitteena on, et- 
tä embargoista luovutaan, kun avoimen julkaisemisen rahoitusmalli saadaan käyttöön. Järjestelmän toimituskäyttö on mahdollista myös perinteisille tilausmaksulla toimiville lehdille.

Syksyn aikana opetus- ja kulttuuriministeriön kanssa sovittiin mahdollisuudesta käyttää tieteellisen julkaisutoiminnan valtionavustusten määrärahasta pieni osa DOI-tunnusten keskitettyyn hankintaan. Tämä on kaikille osapuolille helpoin ja edullisin ratkaisu, jossa jokaisen lehden ei tarvitse maksaa erikseen CrossRef-organisaation jäsenyyttä. DOI:t ovat elektronisille dokumenteille annettavia pysyviä tunnisteita, joiden käyttö parantaa artikkeleiden löydettävyyttä ja linkitettävyyttä.

\section{Journal.fi hyödyttää korkeakoulujen julkaisutiedonkeruussa}

Opetus- ja kulttuuriministeriö kerää vuosittain tietoja tutkimusorganisaatioiden eli korkeakoulujen, tutkimuslaitosten ja yliopistollisten sai- raaloiden tuottamista julkaisuista. Yliopistojen rahoitusmallissa julkaisut muodostavat 13 prosenttia perusrahoituksesta. Rahoitusmallissa huomioidaan tieteelliset, ammatilliset ja yleistajuiset artikkelit ja kirjat. Näistä tieteelliset julkaisut painotetaan Julkaisufoorumi-luokituksen mukaisella painokertoimella.

Julkaisujen täytyy täyttää tiettyjä kriteereitä, jotta ne hyväksytään mukaan tiedonkeruuseen. Kriteereitä ovat julkinen saatavuus, ulkopuolinen julkaisija sekä tekijän yhteys tutkimusorganisaatioon. Lisäksi julkaisun tulee perustua tutkimus- tai asiantuntijatyöhön, eikä se ole saanut aikaisemmin ilmestyä vastaavassa muodossa. Tieteellisten julkaisujen, jotka saavat rahoitusmallissa suurimman painoarvon, tulee olla vertaisarvioituja.

Julkaisuista kerätään suuri määrä erilaisia metatietoja. Kaikkien tietojen ilmoittaminen ei ole pakollista kaikille julkaisuille, vaan pakollisuus vaihtelee julkaisutyypeittäin. Pakollisia tietoja ovat julkaisutyyppi ja tieteenala, raportoivaan

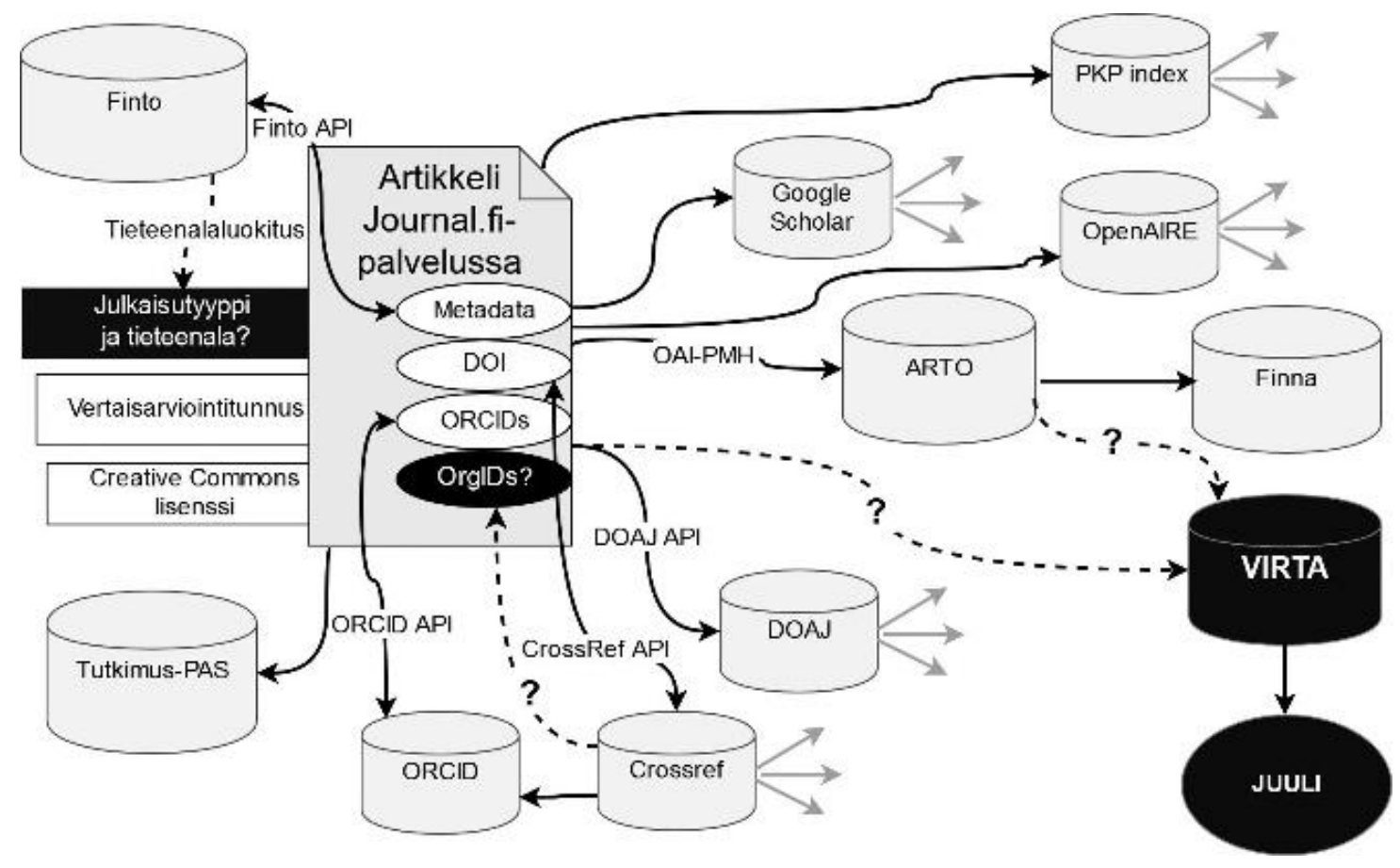

Kuva 2. Journal.fi:n yhteensopivuus muiden palveluiden kanssa. 


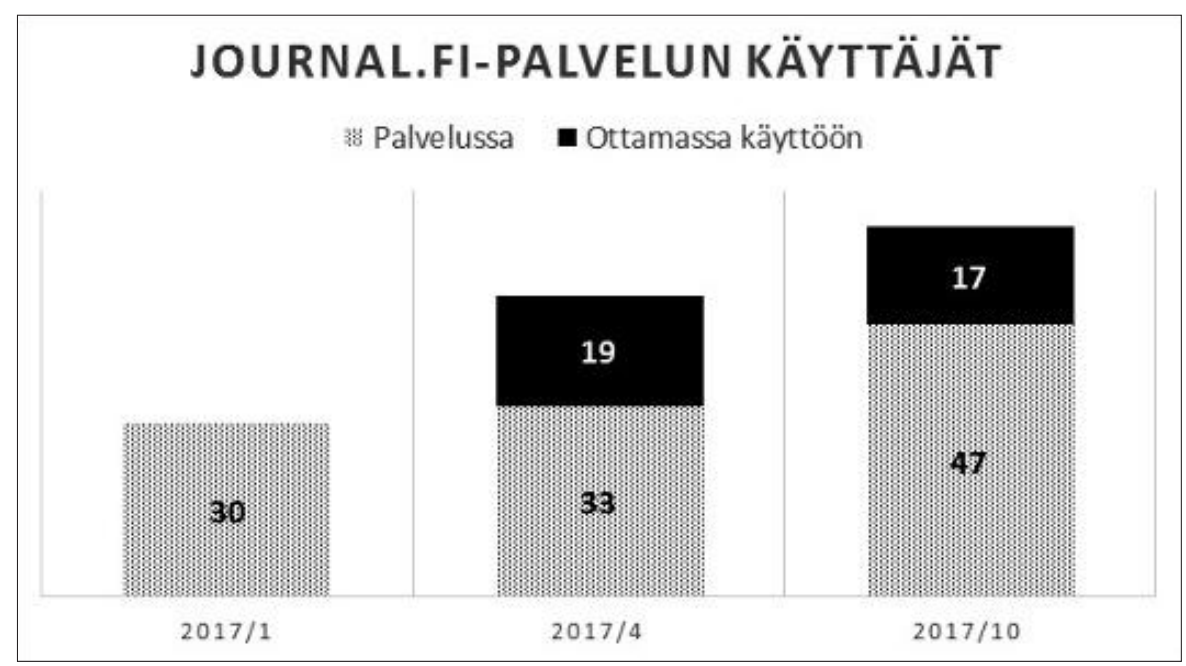

Kuva 3. Journal.fi-palvelun käyttäjämäärien kehitys.

organisaatioon kuuluvien tekijöiden nimet, julkaisun kaikkien tekijöiden nimet, julkaisun nimi, julkaisuvuosi ja avoin saatavuus.

Lisäksi on ilmoitettava, onko kyseessä kansainvälinen yhteisjulkaisu ja, onko julkaisija suomalainen vai kansainvälinen. Joko ISSN- tai ISBNtunnus on pakollinen tieto tieteellisille julkaisuille. Viitetiedoista kysytään myös mm. julkaisun kieltä, avainsanoja, julkaisukanavan nimeä, volyymia, numeroa, artikkelin sivunumeroita, julkaisumaata, kustantajaa, pysyvää verkko-osoitetta sekä julkaisun rinnakkaistallennetun version verkko-osoitetta.

Journal.fi-palvelu helpottaa lähes kaikkien näiden tietojen keräämistä kotimaisten tieteellisten julkaisujen osalta. Palveluun sisältyvien julkaisujen bibliografiset tiedot tulevat saataville Crossrefiin, ARTO-artikkeliviitetietokantaan ja Finnahakupalveluun. Julkaisualustalla on tuki DOItunnisteille sekä tekijät identifioiville ORCIDtunnisteille. Journal.fi myös mahdollistaa tiedonsiirron DOAJ-rekisteriin, eli mikäli lehti on hyväksytty indeksoitavaksi DOAJ:iin, sen artikkelitiedot siirtyvät tietokantaan automaattisesti. Tämä parantaa huomattavasti lehden näkyvyyttä erityisesti kansainvälisen yleisön osalta.

Lisäksi Journal.fi sisältää lisäosan, jonka avul- la Tieteellisten seurain valtuuskunnan vertaisarviointitunnusta käyttävät lehdet saavat helposti tunnuksen näkyviin verkkolehden sisällysluetteloon. Tunnus kertoo käyttäjälle, että artikkeli tai kirja on vertaisarvioitu OKM:n julkaisutiedonkeruun ohjeissa esitetyn määritelmän mukaisesti.

Teknisesti palvelu mahdollistaisi julkaisujen tietojen siirtämisen kansalliseen VIRTA-julkaisutietopalveluun. Tämä kuitenkin edellyttäisi muutoksia ja parannuksia joidenkin metatietojen, kuten affiliaatio- ja tieteenalatietojen, tallentamiseen. Toteutuksen koordinoinnista tulisi myös keskustella Kansalliskirjaston, VIRTA-palvelua ylläpitävän CSC:n, opetus- ja kulttuuriministeriön, TSV:n ja lehtien toimituskuntien kesken.

\section{Maailma ei ole vielä valmis}

Journal.fi -portaali ja OJS 3.0 toimitustyökalu ovat saaneet lehdiltä paljon kiitosta. Uusia lehtiä tuli palveluun kevään aikana lukuisia ja kasvu on jatkunut myös syksyn puolella. Keväällä arvioitiin lehtien määrän nousevan vuoden 2017 loppuun mennessä noin viiteenkymmeneen, mutta tämä määrä tullaan hyvin todennäköisesti ylittämään.

Kustantajien ja kirjastojen yhteistyöllä rakennettu avointen julkaisujen portaali on herättänyt myös kansainvälisesti innostusta, onhan kir- 
jastojen ja kustantajien vastakkainasettelu monessa maassa ollut avoimen julkaisemisen esteenä. Public Knowledge Project on ilmaissut tyytyväisyytensä siitä, että Journal.fi on hyödyntänyt OJS 3.0 -versiota ja tuottanut siitä suomenkielisen käännöksen.

Journal.fi-palveluun kohdistuu kuitenkin edelleen paljon odotuksia. Portaalin tulisi vastata kansainvälisen tason vastaavia palveluita, pysyä teknisesti ajan tasalla ja toimia vakaasti. Järjestelmän on reagoitava nopeasti uusiin tiedejulkaisemisen kehityssuuntiin, kuten XML-muotoiseen julkaisemiseen. Teknisen palvelun lisäksi TSV:n on kyettävä tarjoamaan myös riittävä käyttöön liittyvä tuki julkaisijoille.

TSV pyrkiikin saamaan pysyvän rahoituksen Journal.fi:n ja muiden avoimen julkaisemisen palveluiden ylläpitoa ja kehittämistä varten ensi vuodesta alkaen. Lehtien pysyvä ja välitön avoimuus voidaan turvata vain avointa julkaisemista tukevalla rahoitusmallilla, joten Kotilava-hankkeen rahoitusmallisuunnittelullekin on syytä toivoa menestystä.

\section{Tietoa kirjoittajista:}

\section{Anna-Sofia Ruth, suunnittelija,}

Tieteellisten seurain valtuuskunta

Antti-Jussi Nygård,

Kotilava-hankkeen ma. suunnittelija, tohtorikouluttava Turun yliopistossa

Johanna Lilja, palvelujohtaja, Kansalliskirjasto

Lena Lönngren, julkaisuassistentti,

Tieteellisten seurain valtuuskunta 